\title{
Pharmacognostic investigation of dried powdered Leaves of traditional medicinal plant Gouania longipetala used by pregnant women during Labour for quick and easy delivery in Sierra Leone
}

\author{
Lahai Koroma* ${ }^{\text {a\& b }}$, L.M. Kamara ${ }^{b}$ \\ ${ }^{\mathrm{a} D}$ Department of Basic and Environmental Sciences, Eastern Polytechnic, Kenema, Sierra \\ Leone \\ ${ }^{\mathbf{b}}$ Department of Chemistry, Fourah Bay College, University of Sierra Leone, Sierra Leone \\ acorresponding author: +232 76861935 and E-mail:.lahaikoroma2001@gmail.com
}

Organoleptic evaluation, fluorescence analysis, phytochemical screening and mineral analysison the dried powdered Leaves of $\boldsymbol{G}$. longipetala used by pregnant women before and during Labour for quick and easy delivery in Sierra Leone has been carried out.The grass odour and bitter taste of dried powderedLeaves of the plant helps in identifying and prevent adulteration of the driedpowdered form of the plant organ during organoleptic evaluation. The powdered plant organ also gave fluorescent derivatives with $\mathrm{NaOH}$ solution, ammonia solution, $50 \% \mathrm{HCl}$ and $50 \% \mathrm{HNO}_{3}$ when viewed under UV/Lamp confirming the presence crude drugs in the plant organ investigated.

The results of phytochemical evaluation dried powdered Leaves of $\boldsymbol{G}$. longipetala, revealed moderate to high contents of carbohydrates, alkaloid, flavonoids, proteins sterols/terpenes and saponins in the Ethanolic, methanol and aqueous extract. All of the solvent extracts revealed moderate concentration of Tannins and Phenolic Compounds. The petroleum ether and acetone extracts gave the least concentration of the phytoconstituents investigated. The detection of the above secondary plant metabolites support the use of the plant in traditional medicine

The plant organ investigated contained large amounts of nutrients and was rich in $\mathbf{K}$ (33844 \pm $205.00 \mathrm{ppm}), \mathbf{C a}(27519 \pm 241.00 \mathrm{ppm}), \mathbf{M g}(8954 \pm 2234 \mathrm{ppm}), \mathbf{A l}(20048 \pm 530.00 \mathrm{ppm})$ andFe $(13475 \pm 74.81 \mathrm{ppm})$ which are the main elements responsible for development of foetus during pregnancy. The other elements although present in smaller quantities were $\mathbf{T i}, \mathbf{R b}, \mathbf{S r}, \mathbf{Z r}, \mathbf{Z n}, \mathbf{S c}, \mathbf{V}$, Cuand Mo help in metabolic processes in humans does preventing various types of mineral deficiency diseases in human beings.

Key words: Pharmacognosy, Organoleptic evaluation, fluorescence analysis, phytochemicals, and mineral analysis

Corresponding Author: ${ }^{\text {a Lahai Koroma }}$

\section{INTRODUCTION}

This research is geared towards the Pharmacognostic investigation of dried powderedLeaves of traditional medicinal plant Gouania longipetala used by pregnant women during Labour for quick and easy delivery in Sierra Leone. Medicinal plants play a significant role during pregnancy, birth and postpartum care in many rural areas of theworld[1]. The use of plants to ensure good development ofpregnancy and facilitate labour is a particularly wellestablished practice in Africa [2].However, it has been reported that the required positive effect of the traditional medicinal plants and the effects of such practices on the foetus lifeor on the 
pregnant behaviour during labour required further investigation[2]. The therapeutic efficacy of traditional medicinal plants depends upon the quality and quantity of chemical constituents which are unknown to the traditional healers. The misuse of herbal medicine or natural products starts with wrong identification of the plant. The most common error is one common vernacular name given to two or more entirely different species [3]. Unlike taxonomic identification, pharmacognostic study comprisingOrganoleptic evaluation, Fluorescence analysis, Phytochemical screening and mineral analysis of dried powderedLeaves of traditional medicinal plant Gouania longipetalahelps in identifying adulteration of the driedpowdered form of the plant organ.

\section{GouanialongipetalaHemsl. (Rhamnaceae) Local vernacular names in Sierra Leone [4] \\ Mende: SAWA \\ Kono: $\quad$ FENSAWA \\ Kissi: $\quad$ KOMABENDOE}

GouanialongipetalaHemsl. (Rhamnaceae) is a scandent shrub mainly present in closedforests and in farm lands in Sierra Leone [5]. The Cold decoction of the leaves of $\boldsymbol{G}$. longipetala is given to pregnant women before and during Labour for quick and easy delivery in Sierra Leone[6]. Leaves are macerated in water .and an infusion drunk during the last month of pregnancy to hasten child delivery. A leaf infusion of the plant is also reported in promoting foetus development [7]during pregnancy. The leaves and bark of $\boldsymbol{G}$. longipetalahave also been reported to be used as a cough remedy, while bark, used for sores, and leaves for burns [8].

In Ghana G. longipetalaisreported to be used in the treatment of wounds, venereal diseases, abdominal pain, lumbago, ophthalmia, conjunctivitis, trachoma, malaria [9] waist pain [9] and rickets $[10,11]$. The leaf aqueous extract is used for dropsy, swellings, stomach troubles, as a genital stimulant/depressant, laxative, as a febrifuge and as an antidote for venomous stings, bites etc. [12]. It has been reported that $\boldsymbol{G}$. longipetala helps in diabetes-induced anemia and nephropathy associated with diabetes mellitus [13].

Acute and sub-chronic toxicity profile of methanol leaf extract of $\boldsymbol{G}$. longipetalain rats was investigated and the results suggested that the plant is well tolerated in short term therapies but may have long term toxic effects on the kidney and the liver [14].Antibacterial, antioxidant and anti-inflammatory activities of $\boldsymbol{G}$. longipetalahas been investigated and reported [15].

However, no scientific Pharmacognostic investigationof G. longipetala has been established and hence the aims of this research work.Trace elements are essential components of biological structures that mediate vital effect on and play a key role in a variety of the biochemical processes necessary for life. Excessive levels higher than that needed for biological functions of these elements can be toxic for the body health. Hence any Pharmacognostic investigation of traditional medicinal plantswithout mineral analysis cannot be completed. 

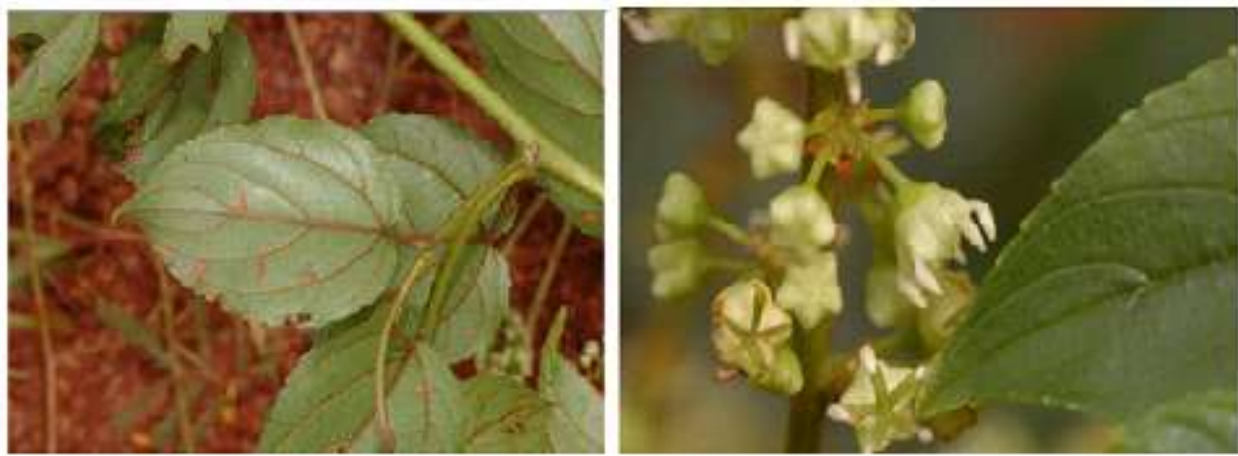

FIGURE 1: Photos of Leaves and Flowers of Gouania longipetala

\section{MATERIALS AND METHODS}

Collection and preparation of dried plant materials

Fresh Leaves of $\boldsymbol{G}$. longipetalawere harvested from the Gola Forest and sun-dried for 4-7 days. The Leaves were not dried on the ground, but on a protective cloth to minimize any microbial contamination. After drying, the Leaves are then reduced in size by cutting into smaller pieces using a cutlass. After the plant material had been dried, it was grounded using a laboratory mill and kept in a proper container until the time of the extraction.

The plant organ investigated is the Leaves of $\boldsymbol{G}$. longipetalawith image of the plant and its flowers shown in Figure 1

A voucher specimen No. 410of the Leaves G. longipetalawas deposited in the Herbarium of the Botany Department, Fourah Bay College (University of Sierra Leone). The powdered plant materialwas used to carry out the following analyses described below:

Organoleptic evaluation

Fluorescence analysis

Phytochemical screening

Mineral analysis

\section{EXPERIMENTAL}

Organoleptic characters

Organoleptic evaluation was carried out on the dried powdered Leaves of $G$. longipetalaby means of sense organs, which provide the simplest as well as quickest means to establish the identity and purity to ensure quality of a particular drug. Organoleptic characters investigated [16] are size, colour, odour, taste and texture of the dried powdered Leaves of G. longipetala. The results are shown in Table 1and the image of dried powdered Leaves of G.longipetalashown in Figure 3.

\section{Fluorescence analysis}

$0.5 \mathrm{mg}$ of dried powdered Leaves of $\boldsymbol{G}$. longipetalawas placed in a glass petri dish free from grease and 2-3 drops freshly prepared reagent solution was added, mixed gentlywith a glass rod and waited for few minutes. The following freshly prepared reagents are used;

Powder $+1 \mathrm{~N} \mathrm{NaOH}(\mathrm{aq})$, Powder $+1 \mathrm{~N} \mathrm{NaOH}$ (alc.), Powder + Ammonia, Powder + Picric acid, Powder + Petroleum ether, Powder $+50 \% \mathrm{HCl}$, Powder $+50 \% \mathrm{H}_{2} \mathrm{SO}_{4}$, Powder $+50 \%$ $\mathrm{HNO}_{3}$, Powder + Ethyl acetate, Powder + Ethanol, Powder + Methanol, and Powder + Bromine water.

The colours of each of the contents in Petri dish were observed in visible light, short (254 $\mathrm{nm})$ and long $(365 \mathrm{~nm})$ ultra violet radiations using a U/V Lamp. A piece of white paper was dipped in each of the solutions and viewed using both visible light and under the U/V Lamp 
to compare the colours obtained. The colours observed by application of different reagents in different radiations are recorded [17] as shownin Table 2.

\section{Phytochemical analysis}

Soxhlet extraction was carried out on the dried powdered Leaves of G. longipetalausing solvents of increasing polarity (i.e. Petroleum ether $\left[60-80^{\circ} \mathrm{C}\right]$, Acetone, Chloroform Methanol, 95\% Ethanol and Water. Each of the solvent extracts was concentrated, reduced to a semisolid mass using a Rotary Evaporator at $50^{\circ} \mathrm{C}$ and kept in special containers for phytochemical screening.

The Phytochemical screening involved testing each of the Solvent Extracts for the various classes of secondary plant metabolites. The methods used for detection of various phytochemicals were followed by qualitative chemical test and by standard procedures [18, 19]to give general idea regarding the nature of constituents present in each of the solvent extracts of the plant part investigated $[20,21,22,23,24,25 \& 26]$. They are generally tested for the presence secondary plant metabolites such as Carbohydrates, alkaloids, tannins/phenolic compounds, flavonoids, Sterols/triterpenes, Amino acids/ proteins and saponins/glycosides etc.

\section{Test for carbohydrates:}

A small quantity each of the Solvent Extracts was dissolved in $5 \mathrm{ml}$ distilled water and filtered. The filtrates were subjected to the following tests to detect the presence of carbohydrates.

Molisch's test:- $1 \mathrm{ml}$ of each of the extract filtrate was treated with 2 drops of alcoholic $\alpha$ naphthol solution in a test tube and $1 \mathrm{ml}$ of concentrated tetraoxosulphate (VI) acid added carefully along the sides of the test tubes. Formation of violet/purple ring at the junction may indicate the presence of carbohydrates.

Test for reducing sugars:

Fehling's test: - $1 \mathrm{ml}$ of each of the extract filtrate was treated in equal volumes with $1 \mathrm{ml}$ Fehling A, 1 $\mathrm{ml}$ Fehling $\mathbf{B}$ solutionsand boiled for one minute. The mixture was boiled for 510 minutes on water bath. The formation of Reddish brown precipitate due to formation of cuprous oxide indicates the presence of reducing sugar.

Benedict's test: - $1 \mathrm{ml}$ of each of the extract filtrate was treated with equal volumes of Benedict's reagent in test tubes. The mixture was boiled for 5-10 minutes on water bath. A change in colour of the solution from blue to green, to yellow or brick-red precipitate depending on amount of test item present indicates the presence of reducing sugar.

\section{Barfoed's Test}

$1 \mathrm{ml}$ of the solvent extract was placed in a boiling tube and $3 \mathrm{ml}$ of Barfoed's Reagent added to it. The mixture was heated in boiling water bath for 7 minutes.

The test is positive if colour of the solution changes from blue to dirty green to greenishyellow and then to Dark yellow precipitate. Brick-red precipitates are seen on top of Dark yellow precipitate.

\section{Iodine Test:}

2-3 drops of iodine solution was added to $1 \mathrm{ml}$ of each of the solvent extracts.

The formation blue-black colour indicates the presence of starch. 
Test for Glycosides:

Test for cardiac glycosides:

Keller Kelliani test (test for deoxysugar):-Each of the Solvent Extracts was treated with chloroform and evaporated it to dryness. $0.4 \mathrm{ml}$ of glacial acetic acid containing a trace amount of ferric chloride was added to it and transferred to a small test tube. $0.5 \mathrm{ml}$ of concentrated tetraoxosulphate (VI) acid was carefully added down the side of the test tube. The formation of a blue colour in the acetic acid layer indicates the presence of glycosides.

Test for Anthraquinone Glycosides:

Borntrager's test: - Each of the Solvent Extracts was boiled with $1 \mathrm{ml}$ of dilute tetraoxosulphate (VI) acid in a test tube for $5 \mathrm{~min}$, filtered while hot. The filtrate or supernatant layer was pipette out and places into a test tube. The mixture was cooled and shaken with equal volumes of dichloromethane. The lower levels of dichloromethane was separated and shaken with half its volume with dilute ammonia. The appearance of a rose pink to red colour in the ammonical layer indicates the presence of glycosides.

Test for Saponin Glycosides:

Froth test: - Each of the Solvent Extracts was treated with water in a semi-micro tube shaken well. The appearance of a persistent froth on the top of the mixture indicates the presence of glycosides.

Tests for Amino acids and Proteins:

Biuret test (General test):- Each of the Solvent Extracts was treated with $1 \mathrm{ml} 10 \%$ sodium hydroxide solution and heated. $2-3$ drops of $0.7 \%$ copper (II) tetraoxosulphate (VI) solution was added to the mixture stirred and allowed to stand for few minutes. The formation of purplish violet colour may indicate the presence of proteins.

Millions Test (for proteins):-3 ml of each of the Solvent Extracts was mixed with $5 \mathrm{ml}$ Million's reagent separately. The formation of white precipitate which on heating turned to brick red indicated the presence of amino acids.

Xanthoproteic Test: Each of the Solvent Extracts was placed in a test tube; $1 \mathrm{ml}$ of conc. $\mathrm{H}_{2} \mathrm{SO}_{4}$ was added to the mixture and boiled for few minutes. $1 \mathrm{ml}$ of ammonia solution was added to the mixture. The formation of a white precipitate which on heating turned yellow and orange on addition of ammonia solution indicates the presence of proteins.

\section{Tests for Sterols and Triterpenoids:}

Libermann-Burchard test

TheeachSolvent Extracts was treated with few drops of acetic anhydride boiled for few minutes. The mixture was cooled and concentrated tetraoxosulphate (VI) acid added down the side of the test tubes. A brown ring at the junction of two layers with the upper layer turning green indicates the presence of sterols while formation of deep red colour indicates the presence of triterpenoids.

Salkowski's test

Each of the Solvent Extracts was treated with chloroform with few drops of concentrated tetraoxosulphate (VI) acid, shaken well and allowed to stand for some time. The appearance of red colour in the lower layer indicates the presence of sterols while formation of yellow coloured lower layer indicates the presence of triterpenoids.

Tests for tannins and phenolic compounds:

Iron (III) chloride test

Small amount each of the Solvent Extracts was shaken with water and warmed. $2 \mathrm{ml}$ of 5\% Iron (III) chloride solution was added and observed. The formation of green or blue colour indicates the presence of phenols. 


\section{Gelatin test}

$1 \%$ gelatin solution containing $10 \%$ sodium chloride was added to each of the Solvent

Extracts. The formation of precipitate indicates the presence of tannins and phenolic compounds.

Iodine test

Each of the Solvent Extracts was treated with diluted iodine solution. The appearance of transient red colour indicates the presence of tannins and phenolic compounds.

Nitric acid test

Each of the Solvent Extracts was treated with dilute nitric acid separately. The formation of reddish to yellowish colour indicates the presence of tannins and phenolic compounds.

\section{Test for alkaloids}

About $500 \mathrm{mg}$ of each of the Solvent Extracts was stirred with about $5 \mathrm{ml}$ of dilute hydrochloric acid separately and filtered. Each filtrate was tested with the following reagents: Dragendroff's test

Few drops of Dragendroff's reagent (solution of potassium bismuth oxonitrate iodide) was added to each filtrate and observed. The formation of orange yellow precipitate indicates the presence of alkaloids.

Mayer's test

Few drops of Mayer's reagent (Potassium mercuric iodide solution) was added to each filtrate and observed. The formation of white or cream colour precipitate indicates the presence of alkaloids.

\section{Hager's test}

Few drops of Hager's reagent (saturated aqueous solution of picric acid) was added to each filtrate and observed. The formation of yellow precipitate indicates the presence of alkaloids. Wagner's test

Few drops of Wagner's reagent (solution of iodine in potassium iodide) was added to each filtrate and observed. The formation of reddish brown precipitate indicates the presence of alkaloids.

\section{Tests for flavonoids:}

\section{Shinoda's test (Magnesium Hydrochloride reduction test)}

$5 \mathrm{ml} .95 \%$ ethanol was added separately to each of the Solvent Extracts. Each mixture was treated with $0.5 \mathrm{~g}$ magnesium turnings and few drops of conc. $\mathrm{HCl}$. The formation of pink colour indicates the presence of Flavonoids.

\section{Lead acetate test}

Lead acetate solution was added a small quantity of each of the Solvent Extracts and observed. The appearance of yellow colour precipitates after few minutes indicates the presence of Flavonoids.

Results of each of the above tests are shown in Table 3

\section{Mineral analysis}

\section{Sample preparation}

Sample was thoroughly washed with pure water and rinsed with double distilled water in order to remove the sand or dust particles and all other surface contamination. The plant sample was then airdried, grounded and homogenized in an agate mortar and sieved through a $250 \mu \mathrm{m}$ diameter sieve. A quantity of $3.0 \mathrm{~g}$ mass of the powdered sample was weighed with an analytical balance and placed in a sample cup holder. 


\section{Sample analysis}

Elemental analysis of the sample was performed with a Niton XL3t GOLDD+ Handheld Xray Fluorescence (Thermo Fisher). The Niton Handheld XRF Instrument uses a Ag-anode Xray tube with a voltage of $50 \mathrm{kV}$ and equipped with a Si-drift detector (SDD). Accurate energy and efficiency calibrations of the spectrometer were made using a certified reference material - SRM 1573a - Tomato Leaves supplied by the International Energy Agency (IAEA), Vienna, Austria. The spectrum acquisition time was $480 \mathrm{sec}$ for the sample and the dead time was around $50 \%$.

$\mathrm{X}$-Ray Fluorescence has long been recognized as a powerful technique for the qualitative and quantitative elemental analysis[27, 28]. It has the advantage of being non-destructive, multielemental, fast and cost-effective. Furthermore, it offers a fairly uniform detection limit across a large portion of the Periodic Table and is applicable to a wide range of concentrations.

In this study, a total of fifteen elements $(\mathrm{K}, \mathrm{Ca}, \mathrm{Mg}, \mathrm{Al}, \mathrm{Ti}, \mathrm{V}, \mathrm{Mn}, \mathrm{Fe}, \mathrm{Cu}, \mathrm{Zn}, \mathrm{Rb}, \mathrm{Sr}, \mathrm{Zr}$, Mo, and Sc) were determined in the dried powdered leaves of Gouania longipetala plant by using EDXRF. The mean concentrations of various metals in the plant sample are shown in Table 4.

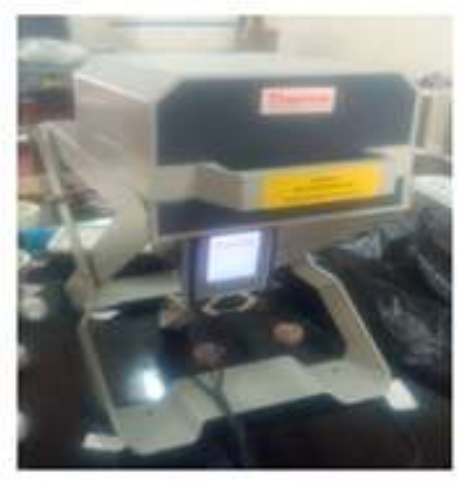

\section{FIGURE 2 : EDXRF used for elemental analysis of} powdered plant sample

\section{RESULTS AND DISCUSSIONS}

Organoleptic evaluation of the dried powdered leaves of Gouania longipetala

The results of organoleptic evaluation of the dried powdered leaves of $\boldsymbol{G}$. longipetala are shown in Table1 with the photo of the dried powdered leaves shown in Figure 2

TABLE 1: Showing the results of organoleptic evaluation on the dry powdered leaves of Gouania longipetala

\begin{tabular}{|l|l|l|l|l|l|}
\hline \multirow{2}{*}{$\begin{array}{l}\text { Plant Organ } \\
\text { Investigated }\end{array}$} & \multicolumn{4}{|c|}{ Property Tested } \\
\cline { 2 - 6 } & Colour & Odour & Taste & Texture & Particle Size \\
\hline Leaves & Brown/green & Grass odour & Bitter & Powdered & 100 \# wire gauge \\
\hline
\end{tabular}

The bitter taste indicates that the powdered plant materials contain alkaloids. The colour of the powdered plant material shown in Figure 3 will also help who so ever wish to buy and use the plant material for medicinal purpose. It helps prevent adulteration. 


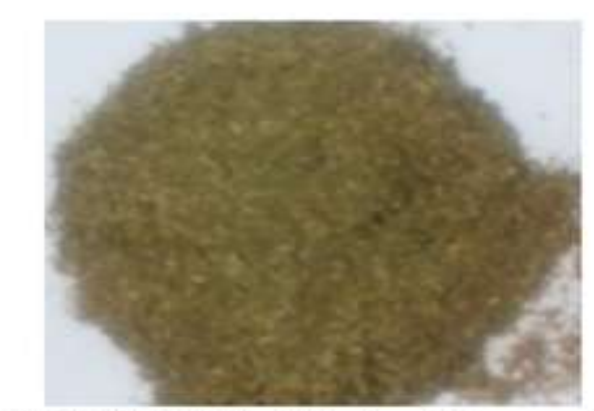

FIGURE 3 : Dried Powdered Leaves of Gouania longipetala

Fluorescence analysis of the dried powdered leaves of Gouania longipetala The results of fluorescent studies carried out on dried powdered leaves of $\boldsymbol{G}$. longipetala using different chemical reagents are reported in the Tables $\mathbf{2}$ below;

TABLE 2: Results of fluorescence analysis the dried powdered leaves of Gouania longipetala

\begin{tabular}{|c|c|c|c|}
\hline Test & Powdered plant material & Visible/day light & Ultra violet light \\
\hline 1 & Powder & Light brown & Light brown \\
\hline 2 & Powder + 1M NaOH(aq) & Light brown & Light orange \\
\hline 3 & Powder + 1M NaOH(alc.) & Light brown & Bright orange \\
\hline 4 & Powder + Ammonia & Light green & Bright orange \\
\hline 5 & Powder + Picric acid & Light green & Yellow \\
\hline 6 & Powder + Petroleum ether & Light brown & Black \\
\hline 7 & Powder $+50 \% \mathrm{HCl}$ & Brown & Light blue \\
\hline 8 & Powder $+50 \% \mathrm{H}_{2} \mathrm{SO}_{4}$ & Brown & dark green \\
\hline 9 & Powder $+50 \% \mathrm{HNO}_{3}$ & Brown & Cream white \\
\hline 10 & Powder + ethyl acetate & Brown & Brown \\
\hline 11 & Powder + Ethanol & Light brown & Black \\
\hline 12 & Powder + Methanol & Light brown & Black \\
\hline 13 & Powder $+\mathrm{Br}_{2}$ water & Light orange & Black \\
\hline
\end{tabular}

The above table showed a colour change in reagents like Powder $+1 \mathrm{M} \mathrm{NaOH}(\mathrm{aq})$, Powder + $1 \mathrm{M} \mathrm{NaOH}$ (alc.), Powder + Ammonia, Powder $+50 \% \mathrm{HCl}$, and Powder $+50 \% \mathrm{HNO}_{3}$.

Some constituents show fluorescence in the visible range in daylight. The ultra violet light produces fluorescence in many natural products which do not visibly fluoresce in daylight. If substance themselves are not fluorescent, they may often be converted into fluorescent derivatives or decomposition products by applying different reagents as illustrated above.

Fluorescence analysis has been reported to be one of the parameters for pharmacognostic evaluation of crude drugs [18] in traditional medicinal plants. Thus the process of standardization can be achieved by stepwise pharmacognostic studies as stated above. This research work helps in identification and authentication of the dried powdered leaves of $\boldsymbol{G}$. longipetala used in traditional medicine. Such information can act as reference information for correct identification of the dried powdered leaves of $\boldsymbol{G}$. longipetala plant and also will be useful in making a monograph of the plant. Further, it will act as a tool to detect 
adulterants and substituents which will help in maintaining the quality, reproducibility and efficacy of natural drugs.

\section{Phytochemical Screening on the dried powdered Leaves of Gouania longipetala}

The results of phytochemical screening using various test reagents for detecting various secondary plant metabolites on the dried powdered Leaves of $\boldsymbol{G}$. longipetala are given in

Table 3 below.

Table 3: Showing the results of phytochemical screening carried out on dried powdered leaves of Gouania longipetala

\begin{tabular}{|c|c|c|c|c|c|c|c|}
\hline \multicolumn{2}{|c|}{ Experiment } & \multicolumn{6}{|c|}{ Solvents } \\
\hline $\begin{array}{l}\text { Secondary Plant } \\
\text { Metabolites }\end{array}$ & Tests/Reagents & $\mathbf{P Z}$ & $\mathbf{A C}$ & CHLO & МeOH & EtOH & Water \\
\hline \multirow{5}{*}{ Carbohydrates } & Molisch's Test & - & + & + & ++ & + & ++ \\
\hline & Fehling's Test & - & + & + & ++ & + & ++ \\
\hline & Benedicts Test & - & + & + & ++ & + & ++ \\
\hline & Barfoed's Test & - & + & + & ++ & + & ++ \\
\hline & Iodine Test & - & + & + & ++ & + & ++ \\
\hline \multirow{4}{*}{ Alkaloids } & Mayer's Test & + & - & - & +++ & ++ & + \\
\hline & Hager's Test & + & - & - & +++ & ++ & + \\
\hline & Wagner's Test & + & - & - & ++ & ++ & + \\
\hline & Dragendroff's Test & + & - & - & ++ & + & + \\
\hline \multirow{4}{*}{$\begin{array}{l}\text { Tannins and } \\
\text { Phenolic } \\
\text { Compounds }\end{array}$} & Iron(III)Chloride Test & - & ++ & ++ & +++ & +++ & +++ \\
\hline & Gelatin Test & - & + & - & +++ & +++ & ++ \\
\hline & Iodine Test & - & ++ & ++ & +++ & +++ & +++ \\
\hline & Dil.HNO $_{3}$ Test & - & + & - & +++ & +++ & ++ \\
\hline \multirow[b]{2}{*}{ Flavonoids } & Shinoda's Test & - & - & - & + & + & +++ \\
\hline & Lead acetate Test & - & - & - & + & + & +++ \\
\hline \multirow{2}{*}{$\begin{array}{l}\text { Sterols/Triterpen } \\
\text { es }\end{array}$} & Libermann-Burchard Test & - & - & + & ++ & + & + \\
\hline & Salkowski's Test & - & - & + & ++ & + & + \\
\hline \multirow{3}{*}{$\begin{array}{l}\text { Amino acids and } \\
\text { Proteins }\end{array}$} & Biuret Test & - & - & - & ++ & ++ & +++ \\
\hline & Million's Test & - & - & - & ++ & ++ & +++ \\
\hline & Xanthoproteic test & - & - & - & ++ & ++ & +++ \\
\hline \multirow{3}{*}{$\begin{array}{l}\text { Glycosides and } \\
\text { Saponins }\end{array}$} & Keller Kelliani Test & - & - & - & ++ & ++ & +++ \\
\hline & Borntrager's Test & - & - & - & ++ & ++ & +++ \\
\hline & Froth Test & - & - & - & ++ & ++ & +++ \\
\hline
\end{tabular}

KEY: PZ = Petroleum ether, $\mathrm{AC}=$ Acetone, $\mathrm{CHLO}=$ Chloroform, $\mathrm{MeOH}=$ Methanol, EtOH = Ethanol; ++ + = Intense $;++$ =Moderate; + = Slight; - = Absent

Petroleum ether, acetone, chloroform, methanol, ethanol and aqueous crude extracts of the dried powdered Leaves of traditional medicinal plant Gouania longipetalaused by pregnant women during Labour for quick and easy delivery in Sierra Leonewas evaluated for the presence of secondary plant metabolites.

The results of phytochemical evaluation reported in Table 3, revealed moderate to high contents of carbohydrates, alkaloid, flavonoids, proteins sterols/terpenes and saponins in the Ethanolic, methanol and aqueous extract. 
All of the solvent extracts revealed moderate concentration of Tannins and Phenolic Compounds. The petroleum ether and acetone extracts gave the least concentration of the phytoconstituents investigated.

The detection of the above secondary plant metabolites support the use of the plant in traditional medicine

Table 4: Showing the total contents of elements (in ppm) in the dried powdered leaves of Gouania longipetala

\begin{tabular}{|c|c|c|c|c|c|c|c|c|}
\hline $\begin{array}{l}\text { Plant } \\
\text { Organ }\end{array}$ & $\mathbf{K}$ & \pm SD & $\mathbf{C a}$ & $\pm \mathrm{SD}$ & Mg & $\pm \mathrm{SD}$ & Al & $\pm \mathrm{SD}$ \\
\hline $\begin{array}{l}\text { Powdered } \\
\text { leaves }\end{array}$ & 33844 & 205.00 & 27519 & 241.00 & 8954 & 2234 & 20048 & 530.00 \\
\hline $\begin{array}{l}\text { Plant } \\
\text { Organ }\end{array}$ & $\mathbf{T i}$ & $\pm \mathrm{SD}$ & V & $\pm \mathrm{SD}$ & Mn & $\pm \mathrm{SD}$ & $\mathrm{Fe}$ & \pm SD \\
\hline $\begin{array}{l}\text { Powdered } \\
\text { leaves }\end{array}$ & 1516 & 26.00 & 47.61 & 9.39 & $<\mathrm{LOD}$ & 19.29 & 13475 & 74.81 \\
\hline $\begin{array}{l}\text { Plant } \\
\text { Organ }\end{array}$ & $\mathrm{Cu}$ & $\pm \mathrm{SD}$ & Zn & $\pm \mathrm{SD}$ & $\mathbf{R b}$ & $\pm \mathrm{SD}$ & $\mathrm{Sr}$ & \pm SD \\
\hline $\begin{array}{l}\text { Powdered } \\
\text { leaves }\end{array}$ & 31.81 & 4.76 & 775.31 & 7.98 & 69.72 & 1.41 & 76.33 & 1.04 \\
\hline $\begin{array}{l}\text { Plant } \\
\text { Organ }\end{array}$ & $\mathbf{Z r}$ & $\pm \mathrm{SD}$ & Mo & $\pm \mathrm{SD}$ & Sc & $\pm \mathrm{SD}$ & & \\
\hline $\begin{array}{l}\text { Powdered } \\
\text { leaves }\end{array}$ & 145.11 & 1.44 & 4.96 & 0.88 & 118.00 & 19.00 & & \\
\hline
\end{tabular}

LOD = Limit of detection (Not available) \pm SD = Standard deviation

The results of the current study as shown in Table 4 revealed that all the metals investigated ( $\mathrm{K}, \mathrm{Ca}, \mathrm{Mg}, \mathrm{Al}, \mathrm{Ti}, \mathrm{V}, \mathrm{Mn}, \mathrm{Fe}, \mathrm{Cu}, \mathrm{Zn}, \mathrm{Rb}, \mathrm{Sr}, \mathrm{Zr}, \mathrm{Mo}$, and $\mathrm{Sc}$ ) were accumulated in greater or lesser extent in the dried powdered leaves ofGouania longipetala plant. The plant organ contained large amounts of nutrients and were rich in K $(33844 \pm 205.00 \mathrm{ppm})$, Ca $(27519 \pm$ $241.00 \mathrm{ppm}), \mathbf{M g}(8954 \pm 2234 \mathrm{ppm}), \mathbf{A l}(20048 \pm 530.00 \mathrm{ppm})$ and $\mathbf{F e}(13475 \pm 74.81$ $\mathrm{ppm})$. The other elements present in smaller quantities were Ti $(1516 \pm 26.00 \mathrm{ppm})$, $\mathbf{R b}$ (69.72 $\pm 1.41 \mathrm{ppm}), \mathbf{S r}(76.33 \pm 1.04 \mathrm{ppm}) \mathbf{Z r}(145.11 \pm 1.44 \mathrm{ppm}), \mathbf{Z n}(775.31 \pm 7.98 \mathrm{ppm})$, Sc $(118.00 \pm 19.00 \mathrm{ppm}), \mathbf{V}(47.61 \pm 9.39 \mathrm{ppm}), \mathbf{C u}(31.81 \pm \mathrm{ppm})$ and Mo $(4.96 \pm 0.88$ $\mathrm{ppm})$. The only element that was out of limit of detection of the equipment was Mn.

Trace elements have several important roles in human bodies. Some are essential for enzymes reactions where they attract and facilitate conversion of substrate molecules to specific end products, donate or accept electrons in redox reactions that are of primary importance in the generation and utilization of metabolic energy, have structural roles and responsible for the stability of important biological molecules [29, 30 and 31].Mg has been reported to a cofactor in more than 300 enzyme systems that regulate diverse biochemical reactions in the body, including protein synthesis, muscle and nerve function, blood glucose control, blood pressure regulation in humans [32, 33 and 34], energy production, oxidative phosphorylation, and glycolysis. It contributes to the structural development of bone and is required for the synthesis of DNA, RNA, and the antioxidant glutathione [35]. It protects mitochondria, which is the storehouse of energy, from the dangerous oxidants [36], transport of calcium and potassium ions across cell membranes, a process that is important to nerve impulse conduction, muscle contraction, and normal heart rhythm [34] andparticipates actively in the 
maintenance of the cardiac rhythm [37] and in constipation. Ca is the main constituent of the skeleton and is important for regulating many vital cellular activities such as nerve and muscle function, hormonal actions, blood clotting and cellular mortality. Iron is an essential element for human beings and animals and is an essential component of hemoglobin. It facilitates the oxidation of carbohydrates, protein and fat to control body weight, which is very important factor in diabetes. Zinc has been reported to be a component of more than 270 enzymes [38] and its deficiency in the organism is accompanied by multisystem dysfunction, sperm manufacture, fetus development and proper function of immune response [39]. Copper is also reported to be an essential nutrient that plays important role in the production of hemoglobin, myelin, collagen and melanin [40].

Low levels of magnesium, manganese, chromium and zinc may cause difficulties in glucose metabolism and can lead to nutritionally induced adult-onset diabetes. These four elements play an important role in the process of breaking down glucose and converting it into energy. The role Magnesium as a catalyst in several hundreds of biological reactions in glycolytic enzymes has been reported [41]. Zinc makes a very specific contribution in the breakdown of carbohydrate and is involved in the granulation and storage of insulin in the beta cells of the pancreas [42].

Deficiency or excess of elements may cause a number of disorders. For example, Iron deficiency anemia affects one third of the world population $[43,44]$ particularly in pregnant women. The high content of iron in the dried powdered leaves ofGouania longipetala plant supports the use of for pregnant women. Low levels of $\mathbf{Z n}$ can induce the pathogenesis of lung cancer and has been reported that breast cancer patients have low levels of $\mathbf{C a}, \mathbf{M g}, \mathbf{F e}$, $\mathbf{C u}, \mathbf{M n}$ and $\mathbf{Z n}$ in their hair [45].

Strontium is reported to be deposited in relative large concentration in bones and teeth, replacing part of calcium in hydroxyapatite crystals [46].

\section{SUMMARY OF RESULTS}

The organoleptic evaluation of the dried powdered leaves of G. longipetala(Table1andFigure 2) showed that the colour of the powdered plant material was brown/green, grass odour with a bitter taste. The bitter taste indicates the presence of alkaloids in the leaves of the medicinal plant $\boldsymbol{G}$. longipetala.

Fluorescent studies carried out on dried powdered leaves of $\boldsymbol{G}$. longipetalausing different chemical reagents gave positive results withthe reagents $1 \mathrm{M} \mathrm{NaOH}(\mathrm{aq}), 1 \mathrm{M} \mathrm{NaOH}($ alc.), Ammonia, $50 \% \mathrm{HCl}$, and $50 \% \mathrm{HNO}_{3}$ ((Tables 2). It is one of the parameters for pharmacognostic evaluation and detection of crude drugs [18]in traditional medicinal plants.

Contents of phytochemical compounds in the dried powdered Leaves of traditional medicinal plant Gouania longipetala varied with the solvent system used (Table 3). Moderate to high contents of carbohydrates, alkaloid, flavonoids, proteins sterols/terpenes and saponins were present in the Ethanolic, methanol and aqueous extract of the plant organ investigated. All of the other solvent extracts revealed moderate concentration of Tannins and Phenolic Compounds. The petroleum ether and acetone extracts gave the least concentration of the phytoconstituents investigated. The detection of the above secondary plant metabolites support the use of the plant in traditional medicine [47, 48, 49, 50 and 51].

The dried powdered leaves ofGouania longipetalaplant was investigated for presence of the following metals $\mathrm{K}, \mathrm{Ca}, \mathrm{Mg}, \mathrm{Al}, \mathrm{Ti}, \mathrm{V}, \mathrm{Mn}, \mathrm{Fe}, \mathrm{Cu}, \mathrm{Zn}, \mathrm{Rb}, \mathrm{Sr}, \mathrm{Zr}, \mathrm{Mo}$, and Sc. The results according to Table 4 indicate that the plant organ contained large amounts of nutrients rich in

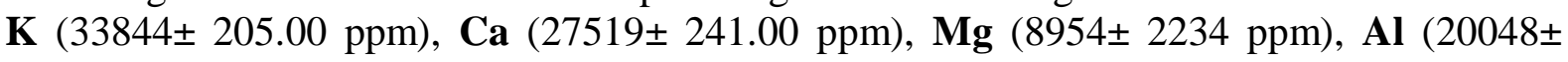
$530.00 \mathrm{ppm})$ andFe $(13475 \pm 74.81 \mathrm{ppm})$ which are essential for the development of foetus in 
pregnant women. The other elements present in smaller quantities were Ti (1516 26.00 ppm), $\mathbf{R b}(69.72 \pm 1.41 \mathrm{ppm}), \mathbf{S r}(76.33 \pm 1.04 \mathrm{ppm}) \mathbf{Z r}(145.11 \pm 1.44 \mathrm{ppm}), \mathbf{Z n}$ (775.31 \pm $7.98 \mathrm{ppm}), \mathbf{S c}(118.00 \pm 19.00 \mathrm{ppm}), \mathbf{V}(47.61 \pm 9.39 \mathrm{ppm}), \mathbf{C u}(31.81 \pm \mathrm{ppm})$ and Mo (4.96 \pm $0.88 \mathrm{ppm})$ and are components of enzymes responsible for the metabolic processes in humans. The only element that was out of limit of detection of the equipment was Mn.

Knowledge of the above elements in medicinal plants is very important since many trace elements play significant roles in the formation of active constituents responsible for the curative properties which cannot be attributed to secondary plant metabolites alone.

\section{CONCLUSION}

Organoleptic evaluation, fluorescence analysis, phytochemical screening and mineral analysiswere carried out on the dried powdered Leaves of $\boldsymbol{G}$. longipetala used by pregnant women before and during Labour for quick and easy delivery in Sierra Leone. The results of organoleptic evaluation, fluorescenceanalysis and phytochemical screening indicate the presence of crude pharmaceuticals that support the use of the plant in traditional medicine. The result of mineral/elemental analysis of the plant indicated that the plant organ investigated contained large amounts of nutrients and was rich in $\mathbf{K}(33844 \pm 205.00 \mathrm{ppm})$, Ca $(27519 \pm 241.00 \mathrm{ppm}), \mathbf{M g}(8954 \pm 2234 \mathrm{ppm}), \mathbf{A l}(20048 \pm 530.00 \mathrm{ppm})$ andFe $(13475 \pm$ $74.81 \mathrm{ppm})$ which are the main elements responsible for pregnant women and the development of the foetus.

The other elements although present in smaller quantities were $\mathbf{T i}, \mathbf{R b}, \mathbf{S r}, \mathbf{Z r}, \mathbf{Z n}, \mathbf{S c}, \mathbf{V}$, Cuand Mo. The human body has an elaborate system for managing and regulating the amount of key trace metals circulating in blood and stored in cells. $\mathrm{Zn}$ is the second most abundant transition metal in organisms after iron and it is the only metal which appears in all enzyme classes, while copper is present in every tissue of the body, but is stored primarily in the liver, with fewer amounts found in the brain, heart, kidney, and muscles.Copper plays an important role in our metabolism, as it allows many critical enzymes to function properly. Copper is essential for maintaining the strength of the skin, blood vessels, epithelial and connective tissue throughout the body. Cu plays a role in the production of hemoglobin, myelin, melanin and it also keeps thyroid gland functioning normally. Iron is involved in the binding, transporting, and release of oxygen in higher animals. Iron, zinc, and selenium are essential components of enzymes where they attract or subtract molecules and facilitate their conversion to specific end products. Some of the trace elements control important biological processes by facilitating the binding of molecules to their receptor sites on cell. Different diseases can be prevented when supplements containing the adequate proportion these elements are taken. Hence their presence in the dried powdered Leaves of G. longipetala supports the use of the plant in traditional medicine.

\section{ACKNOWLEDGEMENT}

The authors are grateful to Mr. Anthony F. Kamara,Department of Physics for carrying out elemental analysis of the dried powdered leaves of Gouania longipetala plant using EDXRF, Laboratory technicians of the Department of Chemistry, Fourah Bay College, University of Sierra Leone and the Principal Eastern Polytechnic, Kenema for providing financial assistance.

\section{REFERENCE}

[1]. De Boer H. \&Lamxay V. (2009) Plants used during pregnancy, childbirth and postpartum healthcare in Lao PDR: A comparative study of the Brou, Saek and Kry ethnic groups. Journal of Ethnobiology and Ethnomedicine2009 ; 5:25. 
[2]. Van Der Kooi R. \& Theobald S. (2006) Traditional medicine in late pregnancy and labour: perceptions of Kgabaremedies amongst the Tswana in South Africa. African Journal of Traditional, Complementary and Alternative Medicines 2006; 3 (1): 11 - 22.

[3]. Dineshkumar C. (2007) Pharmacognosy can help minimize accidental misuse of herbal medicine. CurrSci 2007; 3:1356-1358.

[4]. Deighton, F. C. ( 1957) "Vernacular Botanical Vocabulary of Sierra Leone" 1957, Ed. 1, $17-120$

The Crown Agent for Overseas Governments and Administration, London

[5]. Burkill HM(1985)The useful plants of West Tropical Africa. Royal Botanical gardens Kew, UK

[6]. LebbieAiah R. and Raymond P. Guries (1995)Ethnobotanical Value and Conservation of Sacred Groves of TheKpaaMende in Sierra Leone; Economic Botany, 49 (3), pp. 297 308, (1995)

[7]. Macfoy CA, SamaiAM (1983). Medicinal plants in Pujehun District of Sierra Leone. J. Ethopharm. 8(2): 215-223.

[8]. Samai SK, Barnish G (1992). Some medicinal plant receipts of the Mende of Sierra Leone. 1st ed. Bunumbu Press, Bo, Sierra Leone.pp. 55-93

[9]. Focho, D. A., Ndam, W. T. and Fonge, B. A. (2009) Medicinal plants of Aguambu Bamumbu in the Lebialem highlands, southwest province of Cameroon; African Journal of Pharmacy and Pharmacology Vol. 3(1). pp. 001-013, January, 2009

[10]. Abbiw D. (1990) Useful Plants of Ghana. Intermediate Technical Publications and Royal Botanic Gardens, Kew, UK. 1990

[11]. Burkhill HM. (1994) The Useful Plants of West Tropical Africa. The Trustees of the Royal Botanic Gardens, Kew, UK. 1994

[12]. Maxwell I. Ezeja, Aruh O. Anaga, Isaac O. Asuzu(2014) Effect of Gouanialongipetala (Hemsl.) methanolic leaf extract on the kidney and hematology of alloxan-induced hyperglycemic Wistar rats

[13]. Maxwell, I. EzejaAruh, O. Anaga et al.(2014) Acute and sub-chronic toxicity profile of methanol leaf extract of Gouania longipetala in rats; Journal of ethnopharmacologyISSN ; 0378-8741

[14]. Dickson R, Ekuadzi E, Annan K, Komlaga G. (2011). Antibacterial, antiinflammatory, and antioxidant effects of the leaves and stem bark of Glyphaeabrevis (Spreng) Monachino (Tiliaceae): a comparative study. Pharmacog Res.3:166-172.

[15]. Ekuadzi E, Dickson RA, Fleischer TC.( 2012). Antibacterial, anti-inflammatory and antioxidant properties of GouanialongipetalaHemsl.Int J Pharm Sci Res. 3:13001305.

[16]. Siddiqui, Hakim MA. (1995) Format for the pharmacopoeia analytical standards of compound formulation, workshop on standardization of Unani drugs, (appendix), 24-25 January. New Delhi: Central Council for Research in Unani Medicine (CCRUM); 1995.

[17]. Kokoski J, Kokoski R, Salma FJ. (1958) Fluorescence of powdered vegetable drugs under ultraviolet radiation. J Am Pharm Ass 1958; 47:715-717

[18]. Tatiya A, Surana S, Bhavsar S, Patil D, Patil Y. (2012) Pharmacognostic and preliminary phytochemical investigation of EulophiaherbaceaLindl. Tubers (Orchidaceae). Asian Pac J Trop Disease 2012; 2(Suppl 1):S50-55.

[19]. Harborne JB. (1973)Phytochemical methods. Edn 2. London: Chapman \& Hall, 1973. [20]. Kokate CK. (1997) Practical Pharmacognosy, Edn 4, VallabhPrakashan, Delhi, 107$111,1997$. 
[21]. Zhao Z, Liang Z, Guo P. (2011) Macroscopic identification of Chinese medicinal materials: Traditional experiences and modern understanding. J Ethnopharmacol 2011; 131:556-561.

[22]. Khandelwal KR: Practical Pharmacognosy, NiraliPrakashan, 1995, 149-155.

[23]. Trease E.G. and Evans W.C.(1978)Pharmacognosy 1978, 11th Edition, BalliereTindall, London 115-222.

[24]. Sazada S, Arti V, Ayaz A, Faraha J, Maheswari MK(2009): Preliminary Phytochemical analysis of Some Medicinal and Aromatic Plants. Adv. In Biological Res., 2009; 3(5-6): 188-5.

[25]. Kokate C.K., Purohit A.P. and Gokhale S.B. (2006)Pharmacognosy. $34^{\text {th }}$ Ed. 2006 NiraliPrakashan, Pune, India.

[26]. Nayak BS, Isitor G, Davir EM and Pillai GK. The evidence based Wound Healing Activity of Lawsoniainermis Linn. Phytotherapy Research 2007; 29: 829.

[27]. Queralt I, Ovejero M, Carvalho ML, Marques AF, Liabres JM. (2005) Quantitative determination of essential and trace element content of medicinal plants and their infusions by XRF and ICP techniques. X RaySpectrom 2005; 34: 213-217.

[28]. Shendkar CD, Chandrachood PS, Pawar AB, Lavate SM, deshpande NR. (2011) Quantitative estimation of macro, micronutrients and trace elements by X-ray fluorescence spectroscopy (XRF) from Achyranthesaspera Linn.Int J Chem Tech Res 2011; 3(2) : 610-613.

[29] H. J. M. Bowen, (1976)Trace Elements in Biochemistry, $2_{\text {nd }}$ ed. London: Academic Press.

[30] F. H. Nielsen, J. R. Hunt, (1989) Trace elements emerging as important in human nutrition. In: P. J. Stumbo, (Ed.), Proceedings of the Fourteenth National Databank Conference, Iowa City: University of Iowa, p135-143.

[31] R. M. Douglas, H. Hemilä, E. Chalker, B. Treacy, (2007) Vitamin C for preventing and treating the common cold. The Cochrane Database of Systematic Reviews, 3: CD000980.

[32]. IOM (Institute of Medicine) (1997), dietary reference intakes: Calcium, phosphorus, magnesium, vitamin D and fluoride. Food and Nutrition Board, Washington, DC: National Academy Press.

[33]. R. K. Rude, (2010) Magnesium. In: P. M. Coates, J. M. Betz, M. R. Blackman, G. M. Cragg, M. Levine, J. Moss, J. D. White, (Ed.), Encyclopedia of Dietary Supplements, 2nd ed. New York, NY: Informa Healthcare, p527-537.

[34]. R. K. Rude, (2012) Magnesium. In: A. C. Ross, B. Caballero, R. J. Cousins, K. L. Tucker, T. R. Ziegler, (Ed.), Modern Nutrition in Health and Disease, $11_{\text {th }}$ ed. Baltimore, Mass: Lippincott Williams \& Wilkins, p159-175.

[35]. M. P. Romani, (2013) Magnesium in health and disease. In A. Sigel, H. Sigel, R. K. O. Sigel, (Ed.), Interrelations between Essential Metal Ions and Human Diseases, Metal Ions in Life Sciences, Vol. 13. Ch. 3. Dordrecht: Springer, p49-79.

[36]. L. G. Abbott, R. K. Rude, (1992) Clinical manifestations of magnesium deficiency, Mineral and Electrolyte Metabolism, 19(4-5): 314-322.

[37] Martin Jr, D. W., Mayers, P. A., Rodwell, V. W., Granner, D. K. 1985. Harper's Review of Biochemistry, 20th ed., Lange Medical Publications, California, pp. 651-660.

[38] Zinpro Corporation. 2000. Epithelial tissue: body's first line of defense depends upon trace minerals. Trace Miner Focus. 6: 1-8.

[39] Serfor-Armah, Y., Nyarko, B. J. B., Akaho, E. H. K., Kyere, A. W. K., Osae, S. and Oppong-Boachie, K. 2002. Multielemental analysis of some traditional plant medicines used in Ghana. J. Trace Microprobe Tech. 20: 419-427. 
[40] Cobanoglu, U., Demir, H., Sayir, F., Duran, M. and Mergan, D. 2010. Some mineral, trace element and heavy metal concentrations in lung cancer. Asian Pacific J. Cancer Prev. 11: 1383-1388.

[41]. Guthrie HA: Introductory Nutrition, 3rd Ed. Saint Louis, The C.V. Moshby Co. 1975:1975.

[42]. Bollin Se et al.,: The structure and Metabolism of the Pancreatic Islets. Oxford, Pergamon Press, 1964.

[43] Leterme, P., Buldgen, A., Estrada, F. and Londono, A. M. 2006. Mineral content of tropical fruits and unconventional foods of the Andes and the rain forest of Colombia. Food Chem. 95: 644-652.

[44] Cobanoglu, U., Demir, H., Sayir, F., Duran, M. and Mergan, D. 2010. Some mineral, trace element and heavy metal concentrations in lung cancer. Asian Pacific J. Cancer Prev. 11: 1383-1388.

[45] Joo, N., Kim, S., Jung, Y. and Kim, K. 2009. Hair iron and other minerals' level in breast cancer patients. Bio Trace Elem Res, 129: 28-35.

[46] Shorr E, Carter AC. The usefulness of Strontium as an adjuvant to calcium in the remineralization of the skeleton in man. Bull Hosp Joint Dis. 1952 Apr:13(1):59-66.

[47]. Lahai Koroma and Basil N. Ita (2009)Phytochemical compounds and antimicrobial activity of three medicinal plants (Alchorneahirtella, Morindageminataand Craterispermumlaurinum) from Sierra Leone. African Journal of Biotechnology Vol. 8 (22), pp. 6397-6401, 16 November, 2009

[48]. Musyimi DM, Ogur JA, Muema PM (2008). Phytochemical compounds and antimicrobial activity of extracts of Aspiliaplant (Aspiliamossambicensis) (Oliv) Wild. Int. J. Bot. 4(1): 56-61.

[49]. Weimann C, Heinrich M (1997). Indigenous medicinal plants in Mexico; The example of the Nahua (Sierra de Zongolica) Pharm. Biol. 110:62-72.

[50]. Atindehou KK, Kone M, Terraux C, Traore D, Hostettmann K, Dosso M (2002). Evaluation of the antimicrobial potential of Medicinal plants from Ivory Coast. Phytochem. Res. 16: 497-502.

[51]. Edeoga HO, Okwu DE, Mbaebie BO (2005). Phytochemical constituents of some Nigerian Medicinal plants. Afr. J. Biotechnol. 4: 685-688. 